Wie man sieht, lässt sich also mit einer 200 fachen Vergrösserung, wie eine solche bei Meridiankreisen oder grösseren Passageninstrumenten gut anwendbar ist, eine Genauigkeit erzielen, die bis ungefähr $50^{\circ}$ Declination im Mittel den dreifachen Werth der bisherigen erreicht. Es dürfte aber nicht schwer sein, die Beobachtung an einer (oder mehreren) Stellen des Gesichtsfeldes zu wiederholen und so ein Material zu erlangen, welches in Bezug auf die zufälligen Durchgangsfehler dem jetzigen Tageswerth vollständig aequivalent ist. Eine zufällige Unregelmässigkeit im Gange des Uhrwerks ist hierbei nicht ohne Bedeutung, indem sie die dem Zeitmomente entsprechende Schraubenstellung verfälscht. Jedoch kann sie nach früher Gesagtem nur in der Zwischenzeit $z$ wischen zwei auf einander folgenden automatischen Signalen, welche 0.5 kaum übersteigt, in Frage kommen und muss nach den diesbezüglichen Bemerkungen des Herrn Dr. Cohn über das Königsberger Instrument als sehr gering angenonmen werden. $\mathrm{Um}$ dennoch einem ungünstigen Einfluss von dieser Seite zu entgehen, liesse sich gewiss unschwer eine Einrichtung treffen, welche gestattet, mit dem Moment des Tastersignals das Uhrwerk auszuschalten, worauf dann die Schraubentrommel direct abzulesen wäre.

Was die systematische Ungenauigkeit der Rectascension betrifft, so ist zunächst darauf hinzuweisen, dass der persönliche Fehler in der Wiedergabe des Zeitmoments des Sterndurchgangs - wenn dabei überhaupt von einem solchen gesprochen werden kann - durch den Factor $I: p\left(\overline{<}^{1} / 10\right)$ ganz bedeutend verringert wird, so dass man es hier in dieser Beziehung ebenfalls mit »unpersönlichen» Beobachtungen zu thun hat. Sodann wird ein persönlicher Fehler in der Auffassung des Sternorts bezüglich des Fadens und eine daraus resultirende Helligkeitsgleichung genau in derselben Weise wirken wie beim Pointirungsverfahren, um so mehr als die relative Bewegung ja eine so langsame ist. Dass man denselben aber mittelst eines Reversionsprismas, welches vor dem Ocular in zwei verschiedenen Lagen verwendet wird, eliminiren kann, dass man ebenso die Schraubenfehler durch geeignete Einrichtung der Beobachtungen unschädlich machen kann, braucht kaum erst erwähnt zu werden. Hingegen möchte ich hier auf einen Punkt aufmerksam machen, welcher die vorigen Fragen nicht direct berührt, jedoch in gewissem Sinne störend auf das ganze Verfahren wirken könnte. Wir haben auf hiesiger Sternwarte die Erfahrung gemacht, dass die automatischen Contacte beim Repsold'schen Mikrometer nicht immer absolut zuverlässig sind - ob dies nun Zufall ist, oder ob dieselbe Beobachtung auch anderwärts gemacht wurde, weiss ich nicht; jedenfalls glaube ich, dass sich bessere Resultate erzielen liessen, wenn man statt mit Strom. schluss mit Stromunterbrechungen arbeiten würde, welche durch ein Relais auf den Chronographen übertragen werden und wobei der (schwache) primäre Strom stets nur für die kurze Zeit eines Sterndurchgangs gebraucht wird.

Dem vorliegenden Beobachtungsverfahren könnte vielleicht der Vorwurf gemacht werden, dass es in die alte Registrirmethode verfällt; ich hoffe aber genügend gezeigt zu haben, wie es sich deren schwache Seite fernhält, um gleichzeitig bei der Anhäufung des Materials sich auf ein Minimum zu beschränken. Leider bin ich einstweilen nicht in der Lage meine Ausführungen durch Beobachtungen zu erhärten, dagegen besteht der Plan, den hiesigen kleinen Meridiankreis mit den nöthigen Einrichtungen zu versehen, so dass in nicht zu langer Zeit auch praktische Versuche in dem angedeuteten Sinne angestellt werden können.

Eine Anwendung des. Verfahrens bei Refractoren wäre denkbar unter Benutzung des das Instrument treibenden Uhrwerks (z. B. zur Ausmessung von engen Doppelsternen durch den Faden unter $45^{\circ}$ ), allein der Gang eines solchen wird in den meisten Fällen viel zu ungleich sein, selbst bei Anbringung von automatischen Contacten, welche denselben zu controliren im Stande wären. Viel eher dürfte die Einrichtung eines Repsold'schen Mikrometers mit Uhrwerk am Ocular, zur Bestimmung von Parallaxen in Rectascension eines Versuches werth sein.

Königstuhl, 1902 April 23.

L. Courvoisier.

\title{
Ueber die Doppelsternmessungen am grossen Pulkowaer Refractor.
}

\author{
Von $H$. Struve.
}

In der Mai-Nummer des »Observatory « findet sich eine kurze Besprechung der in den Jahren $1885-1895$ am 30-zölligen Refractor zu Pulkowa angestellten Mikrometer. messungen von Doppelsternen, in welcher das Urtheil ohne nähere Begründung dahin abgegeben wird, dass die Arbeit zwar einige nützliche Beobachtungen enthalte, im Uebrigen aber den an ein so grosses Fernrohr zu stellenden Anforderungen nicht entspreche und über die Leistungen des Instruments keinen Aufschluss geben könne. Ich würde auf diese abfällige Kritik nicht näber eingehen und das Urtheil derjenigen abwarten, welche von diesen Messungen wirklich Gebrauch machen, wenn der Bericht auf die in der Einleitung zur Publication gegebenen Erklärungen Rücksicht genommen hätte, rein sachlich gefasst wäre und nicht eine persönliche Anspielung enthielte, die ich zurückweisen muss.
Im Bericht wird zunächst behauptet, dass das Arbeitsprogramm ein solches sei, welches ebenso gut von einem Fernrohr zweiten oder dritten Ranges hätte ausgeführt werden können: The pairs measured are out of all proportion to the aperture, and would fit ill in a working list for a refractor half the size. \& $\mathrm{Zum}$ Belege wird angefuihrt, wie die Sternpaare sich auf die verschiedenen Ordnungen nach der Distanz vertheilen, woraus offenbar hervorgehen soll, dass die engeren Paare im Vergleich zu den leichter zu messenden weiteren Paaren nicht die gebührende Berücksichtigung gefunden haben.

Nach der Abzählung des Berichterstatters entfällt etwa die Hälfte aller Sternpaare auf Distanzen unter 2", etwa $1 / 3$ auf Distanzen zwischen $2 "-10^{\prime \prime}$ und etwa $1 / 6$ auf Distanzen über I0". Diese Abzählung wäre zunächst dahin zu ergänzen, 
dass fast $2 / 3$ der Messungen sich auf Distanzen unter 2" beziehen. Es sind also thatsächlich die engeren Paare bevorzugt worden. Was soll indessen diese Abzählung eigentlich besagen? Sollen etwa die grossen Refractoren nur auf die Messung der engen Doppelsterne beschränkt werden, und liegt die Bedeutung der grossen Instrumente wirklich nur in der Auflösung der Doppelsterne? Dass man in letzterer Hinsicht mit den grössten Refractoren noch etwas weiter gelangt, als mit Refractoren mittlerer Grösse, wird niemand bestreiten, obwohl hier der Vortheil des kleineren Beugungs bildes zum Theil durch die optischen Unvollkommenheiten und die Unruhe der Luft compensirt wird. Ausser -der $\mathrm{Zu}$ nahme der Lichtstärke und der Abnahme des Beugungsbildes haben aber die grossen Refractoren noch den weiteren Vorzug der langen Brennweite, welcher bedingt, dass mit verhältnissmässig schwach gekrümmten Ocularen schon erhebliche Vergrösserungen erzielt werden, und dieser letztere Umstand ist für die $\mathrm{G}$ e $\mathrm{n}$ a u ig keit der Mikrometermessungen von ganz wesentlicher Bedeutung. Dadurch erklärt sich nämlich die Erfahrung, dass die Ueberlegenheit der grossen Refractoren ceteris paribus schon in den Messungen hellerer Sternpaare - die hellsten vielleicht ausgenommen - sich geltend macht und um so stärker hervortritt, je schwächer die Componenten sind. Sollen ferner Sterne wie 5 Cancri und viele andere bekannte $\mathbf{\Sigma}$-Sterne, für welche genaue Messungen das grösste theoretische Interesse haben und noch für lange Zeit behalten werden, nur deswegen aus dem Pro. gramm eines 3 -Zöllers ausscheiden, weil sie bereits mit kleineren Instrumenten beobachtet werden können? Bei der Werthschätzung von Messungen kommt es doch nur darauf an, welchen Nutzen dieselben gewähren, und ob sie eine den aufgewandten Hülfsmitteln entsprechende Genauigkeit besitzen. Und meiner Ueberzeugung nach ist es eine mindestens ebenso wichtige Aufgabe für die Doppelsternastronomie, die Genauigkeit der Beobachtungen bei den bekannten Doppelsternen zu erhöhen, wie das wiederholte Beobachten aller möglichen sehr engen oder schwierigen Paare, $z$ umal wenn die systematischen Fehler solcher Beobachtungen, wie es gewöhnlich der Fall ist, nicht hinlänglich bestimmt werden.

Aus der betreffenden Notiz lässt sich ferner nicht ersehen, nach welchen Gesichtspunkten die Sterne ausgewählt worden sind. In den Arbeitscatalog waren erstlich alle diejenigen $\Sigma$ - und $O \Sigma$-Sterne nördlicher Declination aufgenommen, welche nach den früheren Messungen grössere Bewegung gezeigt haben, insbesondere also alle Sterne mit rascher Bahnbewegung; ferner diejenigen Sternpaare, welche in Bezug auf Bewegung verdächtig oder in früherer Zeit nicht genügend sicher bestimmt waren. Nach diesem Pro. gramm umfasste der Arbeitscatalog zunächst $430 \quad \Sigma$. und 1 $900 \Sigma$.Sterne. Von diesen sollten die Sterne mit rascher Bahnbewegung häufiger beobachtet werden, während von den andern überhaupt nur zwei bis drei Messungen in Aussicht genommen waren, genügend, um eine sichere Position zu liefern und die Frage zu entscheiden, ob diese Sterne noch weiter zu verfolgen seien. Hinzugefügt wurden dann noch einige Sternpaare, vorzugsweise $\boldsymbol{\Sigma}$-Sterne, die zur Vergleichung mit fruheren Beobachtungen und zur Bestimmung der systematischen Fehler geeignet erschienen. Andererseits wurde von einer regelmässigen Verfolgung von einigen bekannten Doppelsternen, wie Castor, $\gamma$ Virginis etc. gerade mit Rücksicht darauf abgesehen, dass diese Paare sich schon verhältnissmässig leicht an kleineren Instrumenten beobachten lassen. $\mathrm{Ob}$ in letzterer Hinsicht richtig verfahren ist, mag fraglich erscheinen. Wenn ich die Arbeit am 30 Zöller nochmals zu wiederholen hätte, würde ich jedenfalls auf die Beobachtung dieser Doppelsterne mehr Gewicht legen.

$\mathrm{Zu}$ dem obigen Beobachtungsprogramm der $\Sigma$. und $O \Sigma$-Sterne waren ferner etwa $200 \beta$-Sterne, aus den ersten I 2 Catalogen von Burnham, hinzugefügt. Wie ebenfalls in der Einleitung gesagt ist, waren von diesen Sternen, gemäss der schon früher von $W$, und $O$. Struve gemachten Einschränkung, nur solche Paare aufgenommen, bei welchen der Hauptstern nicht schwächer als $\left(8^{m}\right)$ angegeben ist. Diese Einschränkung ist natürlich eine ganz willkürliche und könnte beliebig erweitert werden. Auch kann weder gegen das Aufsuchen, noch gegen das Beobachten von schwächeren Duplices ein Einwand erhoben werden; systematisch durchgeführt würde eine solche Arbeit zu manchen interessanten Resultaten von allgemeiner Bedeutung führen. Es ist aber klar, dass ein jeder Beobachter, wenn er sich nicht ins Endlose verlieren will, bestimmte Grenzen einhalten muss, sei es, dass er diese Grenzen nach der Helligkeit und Nähe der Componenten zieht, oder sich bei der Auswahl nach früheren Beobachtungen richtet. Mit der Beobachtung der obigen $\beta$-Sterne wurde die Arbeit am grossen Refractor gleich nach seiner Aufstellung im Jahre 1885 begonnen und der grössere Theil dieser Sterne im ersten Jahre durchgemessen. Um jene Zeit war erst ein Theil der Burnham'schen Doppelsterne bekannt, insbesondere fehlten noch die wichtigen Entdeckungen am 36 zölligen Lick-Refractor. Für diese letzteren war im Jahre 1892 ebenfalls ein Arbeitscatalog angefertigt. Die geplante Fortsetzung der Beobachtungen Burnham'scher Sterne musste aber aus den in der Einleitung angeführten Gründen unterbleiben. Die Unterstellung, dass no doubt sentiment is very much responsible for the Struve pairs, but this fails to account for the Burnham stars «, bedarf hiernach wohl keiner weiteren Widerlegung.

Ebensowenig ist der Satz verständlich: sthere is a feeling, that great difficulty was experienced in measuring anything under o" 4 c. Bei solchen Sternpaaren kann selbst unter den günstigsten Verhältnissen nur von einer beiläufigen Schätzung der Richtung die Rede sein. Und was Distanzmessungen unter o"4 anbetrifft, so besitzen wir bisher noch kein Mittel, ihre Unsicherheit, die durch das Verdecken der Sternbilder durch die Fäden entsteht, so weit herabzudrucken, dass sie mit den Messungen mittlerer Distanzen von einigen Secunden vergleichbar wären. Die Ansicht, Distanzen unter o"5 durch Messung genauer als durch Schätzung angeben zu können, ist durch nichts bewiesen, und mir erscheinen solche Versuche, denen man gelegentlich begegnet, ganz illusorisch.

Schliesslich möchte ich noch Folgendes bemerken. In der Einleitung zu den Beobachtungen ist auf den ersten Seiten hervorgehoben: I) dass die Messungen der Doppelsterne während des ersten Jahrzehnts weder die alleinige, noch auch die wichtigste Aufgabe am grossen Refractor gebildet haben, sondern nur zu den Zeiten angestellt worden sind, wo sie 
den anderen Arbeiten, namentlich den Beobachtungen der Trabanten der Planeten und den spectroskopischen Beobachtungen nicht hinderlich waren, 2) dass diese Beobachtungsreihe in grösserem Umfange geplant war, wegen des Fortgangs des Beobachters im Jahre 1895 aber unbeendigt geblieben ist. Diese beiden Punkte, die für die Beurtheilung insofern ins Gewicht fallen, als sie einige Lücken in der Arbeit erklären, hätten im Bericht Erwähnung finden sollen. Nach meiner Ansicht hat die Beobachtungsreihe zum Theil wegen dieser Lücken, besonders aber dadurch, dass die Untersuchung über die persönlichen Fehler nicht zum Abschluss ge langt ist, an Werth eingebüsst. Im Uebrigen aber glaube ich durch diese Messungen, unter denen die bekanntesten und wichtigsten Doppelsterne mit wenigen Ausnahmen vertreten sind, gleichwohl einen nützlichen Beitrag geliefert $z u$ haben, wie ihn in gleicher Weise ein kleineres Instrument nicht geliefert haben würde. Ueber die Leistungen des Instruments geben diese Messungen ebenso bestimmte Antwort, wie die um dieselbe Zeit angestellten Beobachtungsreihen der Trabanten.

Königsberg, Mai 1902.

H. Struve.

\section{A new Algol variable 10.1902 Cygni. \\ 1900.0: $2 \mathrm{I}^{\mathrm{h}} 55^{\mathrm{m}} \cdot 2+43^{\circ} 5^{\prime}$ BD. $+43^{\circ} 4^{\prime}$ Ior. \\ (Harvard College Observatory Circular No. 65).}

A striking illustration of the value of the library of glass photographs collected at this Observatory during the past seventeen years has been shown within the last few days. Comet r902 a was discovered by Dr. Brooks on April 14, and it was found that a photograph had been taken here on April 3 with the 8 inch Draper Telescope, approximately in the direction from which the comet came. An examination of this plate was accordingly made by Mrs. Fleming, superposing it upon another plate of the same region taken with the same instrument on March 7, 1900. No trace of the comet was found, and in fact the elements now indicate that it was a little beyond the region covered by the photograph. One star, however, in the constellation Lacerta, according to Heis, but in Cygnus according to the Uranometria Nova, appeared faint on the early plate and bright on that taken later. A further examination showed that this object was the north preceding component of $+43^{\circ} \cdot 410 \mathrm{r}$. Its position for 1900 is $\mathrm{RA} .=2 \mathrm{I}^{\mathrm{h}} 55^{\mathrm{m}} \cdot \mathbf{2}$, Decl. $=+43^{\circ} 5^{2}$. The difference in right ascension of the two components is about 2.0 , the difference in declination, $0: 3$. A further examination showed that the star was generally bright and constant in light, so that it must be a variable of the Algol type. It is not very distant from the remarkable variable star SS Cygni which precedes it $16^{\mathrm{m}}$, and is $44^{\prime}$ south. This last star was discovered at this Observatory in 1896 and is ordinarily faint, becoming suddenly bright at intervals which appear to be irregular. Only one other star, U Geminorum, is known to undergo similar changes. The star, SS Cygni, has been carefully studied here, several hundred photographs having been taken of it. It has also been observed visually on several hundred nights both here and elsewhere, but as yet the law regulating its outbursts of light has not been discovered. Again the advantage of the photographic method is indicated, since each plate taken for SS Cygni can be used for studying the new variable, or any others that may be discovered in this part of the sky, as well as if taken for each alone, while of course the visual observations of SS Cygni can be used for no other star. The total number of plates showing the new variable at full brightness is 388 , of which 1 was taken in 1889 , 10 in 1890 , 12 in 1891,8 in 1892,9 in 1893 ,
3 in 1894,10 in 1895,37 in 1896,184 in 1897,30 in 1898,37 in 1899,28 in 1900,7 in 1901 , and 12 in 1902. Besides these, the star appears on 54 photographs taken with the 2.5 inch Anastigmat, but they have not been in. cluded in the present discussion, since the proximity of the other component in some cases renders it difficult to decide whether the variable is at its full brightness, or not.

Besides these plates, 19 were found on which the variable, which ordinarily has the magnitude 8.9 , was of the magnitude 9.3 or fainter. They are enumerated, together with six others taken later, in Table I, which gives in the first three columns the year, month, and day, the Greenwich Mean Time of the middle of the exposure in hours and minutes, and the Julian Day and thousandths. The fourth column gives the photographic magnitude, and the fifth, the correction to the minimum corresponding to this magnitude. A positive sign denotes that the photograph was taken before minimum, a negative sign, after. When the star was not seen, the plus and minus sign is used to indicate that the correction may have any value within the limits given. Thus, the star was of the magnitude 10.5 for about 0.7 I before and after minimum, and accordingly any correction between +od. $\mathrm{I}$ and $-0.7 \mathrm{I}$ may be applied to the observed time of the second plate without indicating an error in the observation. All of these values are derived from the light curve found as described below. At first the period was thought to be 1.498 , but this was found to be an error. The true period appears to be about $31 \% 304$, and the times of minimum are represented by the formula

$$
2410015.05+31.304 E .
$$

The value of $E$, and the residual found by subtracting the computed time of minimum from the time of the photograph, are given in the sixth and seventh columns. The eighth column gives the corrected residual found by taking the algebraic sum of the fifth and seventh columns. The letter $F$ is inserted when the variable was invisible, and the phase is less numerically than the correction given in the fifth column. In these cases, no correction to the period is in. dicated. The letter $M$ is inserted when the phase is less than \pm 0.45 and the variable is of the magnitude $1 \mathrm{I} .4$, or 